\title{
Leigh Hunt Association Books
}

\section{U T H E R A. B R E W E R}

[Editor's note-Luther A. Brewer, of Cedar Rapids, Iowa, collector of the major portion of the magnificent Leigh Hunt collection now in the University Library, was the ideal book collector. He not only collected tirelessly and enthusiastically but he read and studied his books carefully and transcribed every autograph letter, manuscript, or fragment. The last four years of his life, from approximately 1930 to 1933 , were devoted chiefly to the writing of the bibliography, My Leigh Hunt Library, which was planned in three volumes. The first volume, The First Editions, appeared in 1932. The second volume, The Holograph Letters, was published posthumously by the University of Iowa in 1938. The third volume, Huntiana and Association Books, was completed by Mr. Brewer before his death, but it has never been published. The Library has two copies of the typescript. Mr. Brewer's bibliography is not a "bare-bones" listing of books, articles, and manuscripts, but rather a series of graceful essays through which the author makes Leigh Hunt come to life and in which we can clearly see $\mathrm{Mr}$. Brewer's great enthusiasm for his collection and his affection for Leigh Hunt. The following essay is abridged from Chapter Eight of the third volume of $\mathrm{Mr}$. Brewer's work.-F.S.H.]

It is a good practice to read with pen in hand, marking what is liked or doubted. It rivets the attention, realizes the greatest amount of enjoyment, and facilitates reference. It enables the reader also, from time to time, to see what progress he makes with his own mind, and how it grows towards the stature of its exalter.-Leigh Hunt, Imagination and Fancy.

My Hunt library contains a number of association volumes that have interest. They reflect the literary views of their former owner. It was Hunt's habit to mark freely the books he read. Sometimes these markings took the form of underscorings of lines; sometimes perpendicular lines were drawn to include a paragraph that appealed to him; a check mark was employed occasionally. But most pleasing of all to us was his habit of writing in the margin comments on the text. Frequently these were both numerous and extensive; at times they were caustic in their criticism; then again they were commendatory and informing. 
There are many caustic marginal notes in my copy of Ruskin's Modern Painters, the second edition, London, 1844, e.g.: on page 206 Ruskin praises Turner's sunsets and criticises those of Claude, leading Hunt to write: "It may be so, or it may not. Evidence only can shew. Our author has not yet proved, though he has strangely and ingeniously asserted, that Claude and others may not have given truer and more lasting impressions of Nature with their generalities, than Mr. Turner with all his particulars. And meantime the violent and disrespectful tone of his assumptions is against him." Where Ruskin asks, "why then do you blame Turner because he dazzles you," Hunt answers, "Because his dazzle is false, not because it is dazzling. A conflagration of carrots is not a blaze of precious stones." And there are many other notes equally as caustic in this attractive book.

In the collection is a set, six volumes, of Napier's Florentine History, London, Moxon, 1846. On the half-title is the inscription: "To Leigh Hunt Esqr. with the Author's Respectful Compliments." Hunt has inscribed the title-page, "Leigh Hunt. Given him (see fly-leaf) by the excellent author." All six titles bear his autograph signature, and there are marginal notes throughout amounting to three thousand words or more.

"Captain Napier," says Hunt, "though prejudiced in favour of a Florentine liberty in which his own book has forced me to disbelieve, is a man of an honest and fine nature, and has been unable to help saying things of Lorenzo, which upon the whole tell, I think, far more for him than against him and leave an admirer of him like myself justified in retaining his first impression." "Independent of religion!! How can religion, that is to say the Roman Catholic Religion, be excepted from the charge of inefficacy in Italian history? or any history?"

Hunt underscores in the text the words "for ever," and thus protests in the margin: "Why do not historians leave off repeating these foolish words 'for ever.' How do they know? How can they possibly tell? and where is the common-sense or modesty of thus pretending to gauge futurity? They will answer that the words are mere words; that it is a way of speaking \&c. But words often repeated become things; found opinions; and do a world of mischief."

Napier states that the poor are "the most injured by God and therefore most interested in good government"; and this starts Hunt to writing: "This, as we have seen before,-indeed seen throughout,-was a favourite sentiment with Leopold. Its common sense (phrase truly of intense propriety on such a theme) its 'common sense' stares one in the face through rags, hungers, and multitude. Yet in money-worship- 
ping England at this moment, notwithstanding all her good sense and even liberality in many respects, the persons who are thought the most interested in good government are the holders of property;-not indeed by certain radicals and liberals, nor by the very poorest poor; but all the rest talk of 'stakes in the country,' and ask if they are not the most interested in good government who have 'most to lose'-Yes, 'most to lose' undoubtedly; but then it is thought that this 'most to lose' is money; forgetting health, daily comfort, rest, hope. A punster is the man to make the best answer to the phrase, 'stake in the country.' However, we are getting on; and an Englishman in the reign of Victoria can read many parts of this book without blushing." And so on and so forth. Leigh Hunt found the markings and underscorings and the commenting "good to the last" page.

Copious autograph notes enrich Leigh Hunt's copy of Christianity and Infidelity, by S. S. Hennell, London, 1857. His autograph is on the title page, and throughout the volume are about six hundred words of comment by Hunt, besides numerous underscorings and other markings. At the end of the text he has signed his initials and written the date, July 14th, 1857, and the expression, "Amen, So be it." Where the text states that we have none of those "private details of family circumstances" regarding Jesus we should expect, Hunt wrote: "His family are stated (at least some of them) to have thought him out of his wits; and the history of his carpentry, \&c., might have been thought inadvisable."

In 1805 was issued in London by Longman, Hurst, Rees, and Orme, a publication in three volumes entitled Specimens of Early English Metrical Romances, by George Ellis. The first volume is in my collection with Leigh Hunt's autograph signature on the title page and marginal notes and markings throughout the text. Many of the author's statements are questioned by Hunt. Some of his notes are especially interesting: "Strange, that the author should omit Spenser's use of it." "Very natural that false writing should provide bad spirits, and true drive them away." Hunt evidently did not place confidence in the criticisms of Joseph Ritson, as witness the note: "Ritson treated as he deserves. He was a very clever arrogant fool."

Hunt's copy of Scelta di Sonetti, 1735, has a double association interest in that the volume has had homes both in the library of Leigh Hunt and in that of his American friend, James T. Fields, the latter of whom presented it to T. W. Parsons, a contributor in the early days to the Atlantic. Hunt's autograph is on the title page, and he has written on the back inside cover a list of Italian sonnets in the text of the book 
to which he desired to call attention. A number of these sonnets were selected by him for inclusion in a book of sonnets by Italian poets, with notes, which Thornton Hunt seems to have prepared for publication, according to his copy in my collection.

Leigh Hunt makes various references in his writings to Thomas Warton, one-time professor of poetry at Oxford. This fact adds to the interest of the 1840 edition of The History of English Poetry, by Warton, three volumes, each title page carrying Hunt's autograph signature. Rich are the markings and the marginal notes given the volumes by Hunt. One can picture easily the delight taken by him in perusing the pages of this work. Here is an illuminating marginal note: "Dante, partly by his own violent and resentful passions, felt himself dragged down into what, being contemporary life, might be felt by him as common life, and thought he could not assume 'a tragic style' accordingly; little thinking, it seems, how tragical in a grand as well as objurgatory sense posterity would consider it." He notes that "Boccaccio (strange to say) has no ear in these verses, nor indeed any seeming attempt even at decent melody." Warton frequently is criticized by Hunt, especially in his remarks on Chaucer. Warton speaks of the humility of Henry the Fifth when he entered London after the battle of Agincourt, leading Hunt to remark: "Henry (with leave of his renown) was a sickly Methodist, very different from the 'Hal' of Shakespeare; though very likely he had partaken of the 'sins' without the virtues of the tavern." On page 343 of Vol. II reference is made by Hunt to the admiration of Keats for a line in a Rowley poem. Where Warton speaks of the refinement of hunting, Hunt cannot resist noting "or the comforts of the stag? or the manly dignity of the hare-hunter!! Warton is here forgetting his better nature in favour of custom." Here is a fine comment anent one Douglas, a Scotch poet: "Douglas is full of materials for poetry, rather than poetry itself. His descriptions though occasionally good, consist chiefly of a heaping up of matters of fact, without light, shade, or judgement. I remember reading some of him to Keats once, and upon asking what he thought of him, when I had finished he said, 'He is a curious old fellow, poking about.' That is just the man. He sees a wide landscape microscopically."

This is a meaty volume, thus annotated, a charming one to own.

Ever fond of Spenser, Hunt marked freely and doubtless sympathetically his copy of Spenser and His Poetry, by Geo. L. Craik, 3 vols., (small $8 \mathrm{vo}$.) London, 1845. Thenot, in the second eclogue of The Shepherd's Calendar, says he never complained, never was a foeman to fortune,

But gently took that ungently came.

Students of Hunt know that he received the blows that came to him in 
that manner. and hence can appreciate the underscoring he has given this line. And again:

But my flowering youth is foe to frost,

My ship unwont in storms to be tost.

Marked also is the commentator's remark that "men of years have no fear of God at all, or not so much as young folk. For that, being ripened with long experience, and having passed many bitter brunts and blasts of vengeance, they dread no storms of fortune, nor wrath of God, nor danger of men." Rich indeed are these three volumes, so generously marked by a sympathetic spirit.

The first volume of Mrs. Shelley's Essays, Letters From Abroad, London, 1840, is in the collection with Leigh Hunt's autograph signature on the title page, and with rich markings in Shelley's "A Defence of Poetry." Hunt's comments are made freely. Interesting is this estimate of Shelley which appears on page 46: "Shelley wanted only one thing to complete the orb of his greatness,-the discovery that evil was not evil, but only a husk of progression, without which future good could not be? All which is good is only the best and eternal good? Fugitive evil is good for something, even if it be only for the good resulting from its rejection? But a man may believe this, or think the belief necessary and true, and remain an atom in comparison with him who could properly feel and speak all the rest."

An association book to treasure is my copy of the Life and Works of Robert Burns, edited by Robert Chambers, 4 vols., 8vo., Edinburgh, 1851. It was given by the author to Leigh Hunt, who later transferred it, according to this inscription on the title page: "To Charles and Mary Cowden Clarke, for companionship now and then, with their loving friend, Leigh Hunt. Oct. 7th, 1856." On the verso of the half-title, in the autograph of Cowden Clarke, appears this note: "Mr. Robert Chambers gave this book to Leigh Hunt, who transferred the gift to us."

Hunt did not fail to read and annotate the volumes while they were in his possession. His autograph is on each title page; perpendicular pen strokes emphasize numerous paragraphs, and the marginal notes by him are many.

The editor quotes a poem to Burns by Lord Sidmouth, to which Hunt attaches this marginal note: "Bravo, Henry Addington, Lord Sidmouth. I salute thy gentle ghost, my second patron; and rejoice to find that thou couldst write verses so good and true." There is a discussion of the rather niggardly appointment of Burns to the position of exciseman, which causes Hunt to exclaim: "Credat officina; and could not the gratitude of all Scotland have gifted him with a couple of hundreds a year?" Hunt 
cannot resist a dig at royalty. Mr. Chambers notes that no "movement was made in high quarters to distinguish" Burns by state patronage, which gives Hunt the opportunity of saying: "It was because the poet still talked of the people and liberty. They could not bear that talk, however 'guarded,' and still less because of its being 'felicitous.' Think of George the Third and Queen Charlotte 'attending to Burns,' and Pitt 'smiling' upon him!"

An outstanding association book in the collection is a copy of The Meditations of Marcus Aurelius Antoninus, 1692, translated and edited by Meric Casaubon. On the first fly-leaf, in Thomas Carlyle's autograph, is the inscription: "Mary C. Aitken, her book. Chelsea, T.C. 1877." The writing is in the trembling hand of the aged author. On the second fly Hunt has written:

How charming is divine philosophy!
Not harsh and crabbed
But musical as is Apollo's lute.

On the verso of this leaf is the presentation note: “No un-Christian present at Christmas, either in poverty outside or riches within, to dear Thomas Carlyle from his affectionate friend Leigh Hunt. December 27, 1836."

At the time Carlyle and Hunt were near neighbors in Chelsea, and the staunch Presbyterianism of Carlyle and the liberalism of Hunt frequently clashed. Leigh Hunt's autograph is on the title page.

Hunt, early in his readings of the Meditations, began his work of underscoring. The first words so treated are, "To content myself with a spare diet." His son Thornton speaks of the frugality of his father in regard to food: It "was often nothing but bread and meat at dinner, bread and tea for two meals of the day, bread alone for luncheon or for supper." In this same paragraph are marked the words of the text that state that the philosopher was directed to get good and able teachers, and not to complain if they were obtained at excessive charges. A note in the margin in Hunt's autograph reads: "One of the truest of all economies, where it can be afforded."

One can imagine the readiness with which Hunt marked these lines: "Of him [Apollonius] also I learned, how to receive favours and kindnesses (as commonly they are accorded), from friends, so that I might not become obnoxious unto them, for them, nor more yielding, and yet so that I should not pass them neither, as an unsensible and unthankful man."

And note his marginal comment: "This is very delicate and noble." 
We recall Hunt's theory about gifts: ready to accept them as his right and due from friends able to give them, and not under especial obligations to return them.

On page 126, at the end of the text of the Sixth Book, is this informative line: "Down to here in S.J." The book was with Hunt while he was in prison for libeling the Prince Regent, and the calm philosophy of Marcus Aurelius must have been a comfort to the militant reformer.

This precious little volume is not so prolific with Hunt's markings after he left prison, marginal notes being altogether absent. But there are some underscorings none-the-less emphatic and indicative.

One of the scarcer of Leigh Hunt's books is Christianism: or Belief and Unbelief Reconciled, privately printed in London, 1832, at the expense of John Forster. In addition to the two presentation copies described in the first of the volumes telling of my Leigh Hunt library, the collection has been enriched by the acquisition of a third copy from the sale in London in 1932 of the Thomas Carlyle library. On the half-title in John Forster's autograph is this presentation inscription: "To the writer of the article in the Edinburgh Review, entitled "Characteristics'." Beneath these lines Thomas Carlyle has written, "From Leigh Hunt (first acquaintance, 36 years ago!-T.C. 1868)." Attached to the front fly-leaf is a small piece of paper containing in Forster's autograph these words: "If the gentleman to whom this book is sent, will have the goodness to acknowledge the receipt of it, as soon as it arrives,-in a note addressed to Mr. Moxon Bookseller No. 64 New Bond Street,-it will be considered a kindness." This note also has been endorsed by Carlyle: "Came with Hunt's Meditations; has been thumbing about the house for 11 years now. Octr. 1843." Also attached to the front-fly is a note in Carlyle's autograph reading:

4 Ampton Street, 8th Feby. 1832 (Gray's Inn Road). The writer of the Article, "Characteristics," has just received, apparently from Mr. Leigh Hunt, a small volume entitled "Christianism," for which he hereby begs to express his thanks. The volume shall be read: to know the Author of it personally would doubtless be a new gratification.

- Thomas Carlyle

This is the identical copy, the giving of which to Carlyle brought about the acquaintanceship between Hunt and himself. 